\title{
CHANGES OF THE FORMER POND AT FURMANÓW (OLD-POLISH INDUSTRIAL DISTRICT, CENTRAL POLAND) CARTOGRAPHIC AND SEDIMENTOLOGICAL DATA
}

DOI: $h$ ttps://doi.org/10.18509/AGB.2020.21

UDC: $911.374 .4: 528.937: 502.174(438)$

\section{Karolina Fularczyk, Piotr Kusztal, Tomasz Kalicki}

Institute of Geography and Environmental Sciences, Jan Kochanowski University in Kielce, Poland

Corresponding author: fularczykkarolina@gmail.com

\author{
submitted: 11.03 .2020 \\ accepted: 30.05 .2020 \\ published: 15.09 .2020
}

\begin{abstract}
In the last centuries, the studied area belonged to the Old-Polish Industrial District (OPID), where appropriate environmental conditions have contributed to the development of mining and metallurgy based on hydropower. This activity led to changes of valley floors and river network, which are visible on historical and contemporary cartographic materials, as well as in the relief and sediments. This work is a case study of a former water reservoir at Furmanów in the Czarna Konecka river valley (Poland).
\end{abstract}

Keywords: relief and river network changes, human impact, Old-Polish Industrial District, last centuries

\section{INTRODUCTION}

The study area of former industrial pond at Furmanów is located in the Czarna Konecka river valley. It drains NW Mesozoic margin of Holy Cross Mts. in central Poland and belongs to the Vistula basin (Fig. 1). Due to the favourable environment (iron ore deposits, forests and accessibility of hydropower), mining and metallurgical activity developed in this region in the last centuries. There was Old-Polish Industrial District (OPID), which in the 17 th century was the most important centre of metallurgy in the Crown of the Kingdom of Poland [1].Ironworks at Furmanów functioned between 1662 and 1674 [2]. In 1830 s a blast furnace plant was opened up [3]. At the same time, the anthropogenic small system of surface water retention was extended, as indicated by the radiocarbon dating of one of the dike of the industrial pond [4]. After the fire in 1878, this metallurgical plant was rebuilt according to modern French designs (new technical devices have been introduced). After 1890, water wheels were dismantled. The production was based on three steam turbines, whose power was equal to that of all the machines powering the nearby manufactures [3]. This is one of the earliest examples of resignation from water wheels as an energy source in OPID.

From the turn of the 19th and 20th century, the amount of blast furnaces was decreasing in this industrial region [1]. The plant at Furmanów halted production in 1907 [3], four years after a catastrophic flood (1903), which destroyed its infrastructure [5]. It was caused by management problems, as well as by the unfavourable political and social situation which caused the regress in iron production [3]. Today, the ruin of the former blast furnace plant at Furmanów (Fig. 2, A in Fig. 3) are partially restored. Metal sieves are produced here. The area of the former reservoir is swampy (Fig. 3), in some places terrestrialized. 


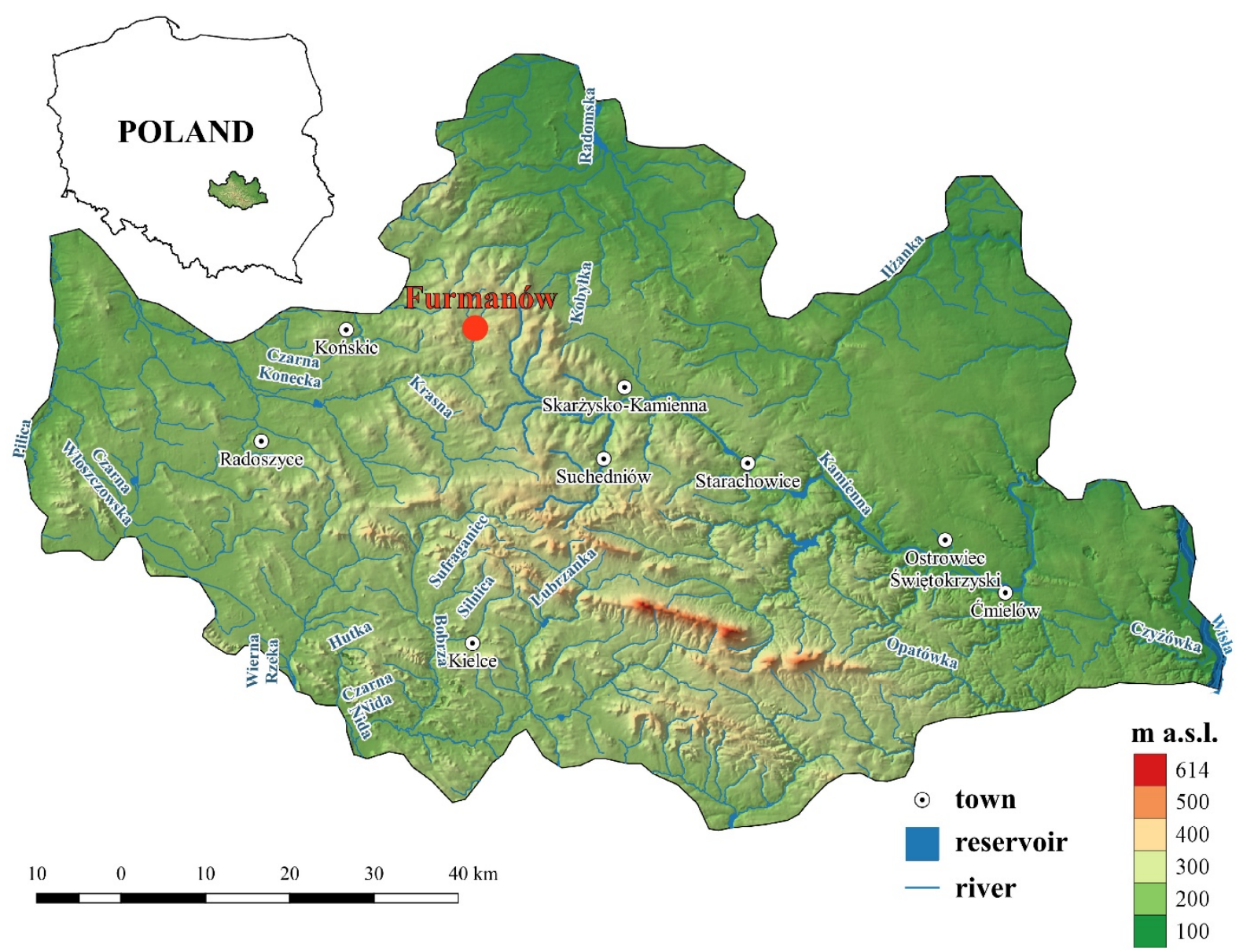

Figure 1. Location of study site (red dot) in the Old-Polish Industrial District (OPID). Limit of OPID according to A. Borkiewicz [6]

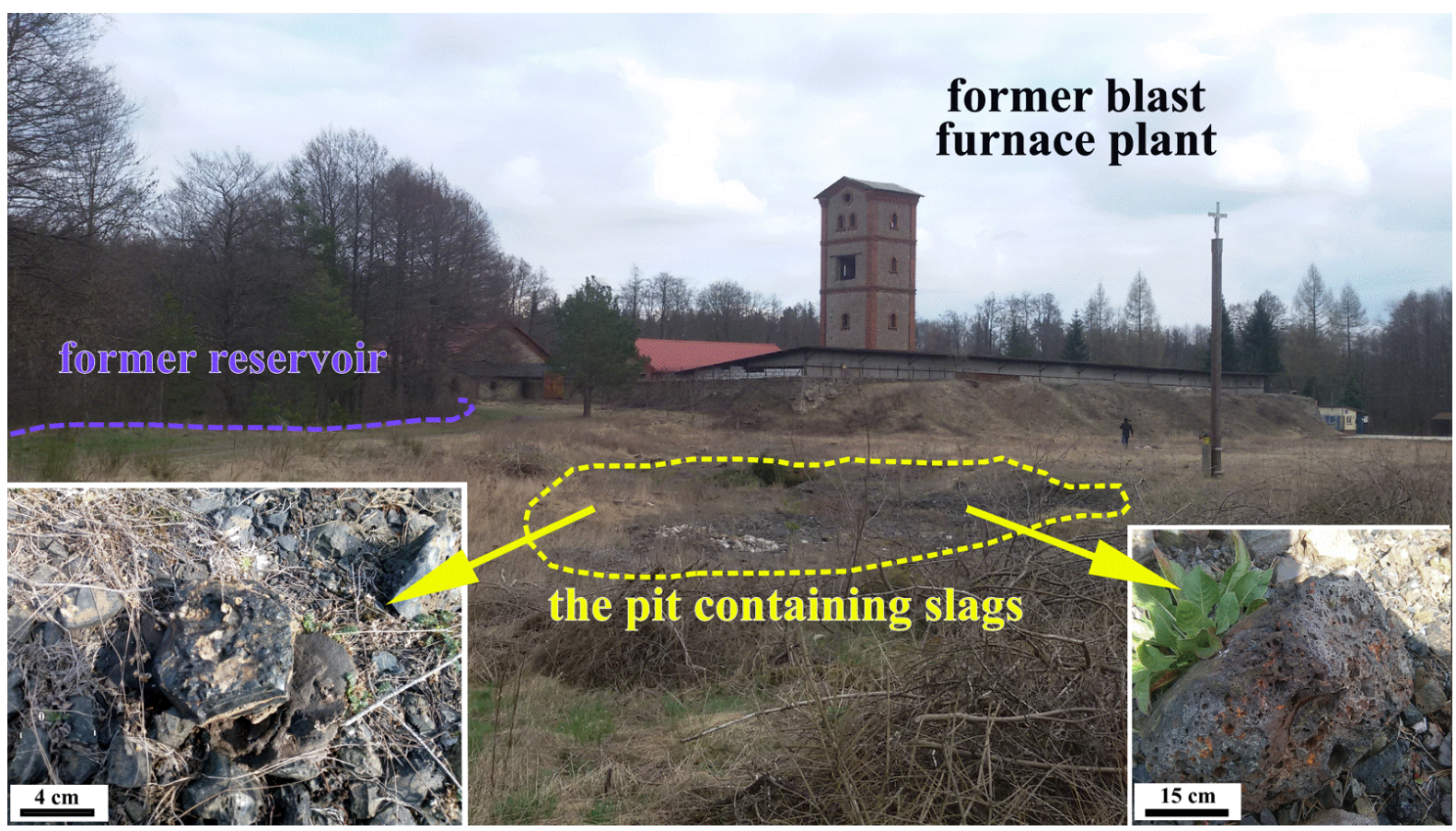

Figure 2. Present-day view of area near the former blast furnace plant at Furmanów. 


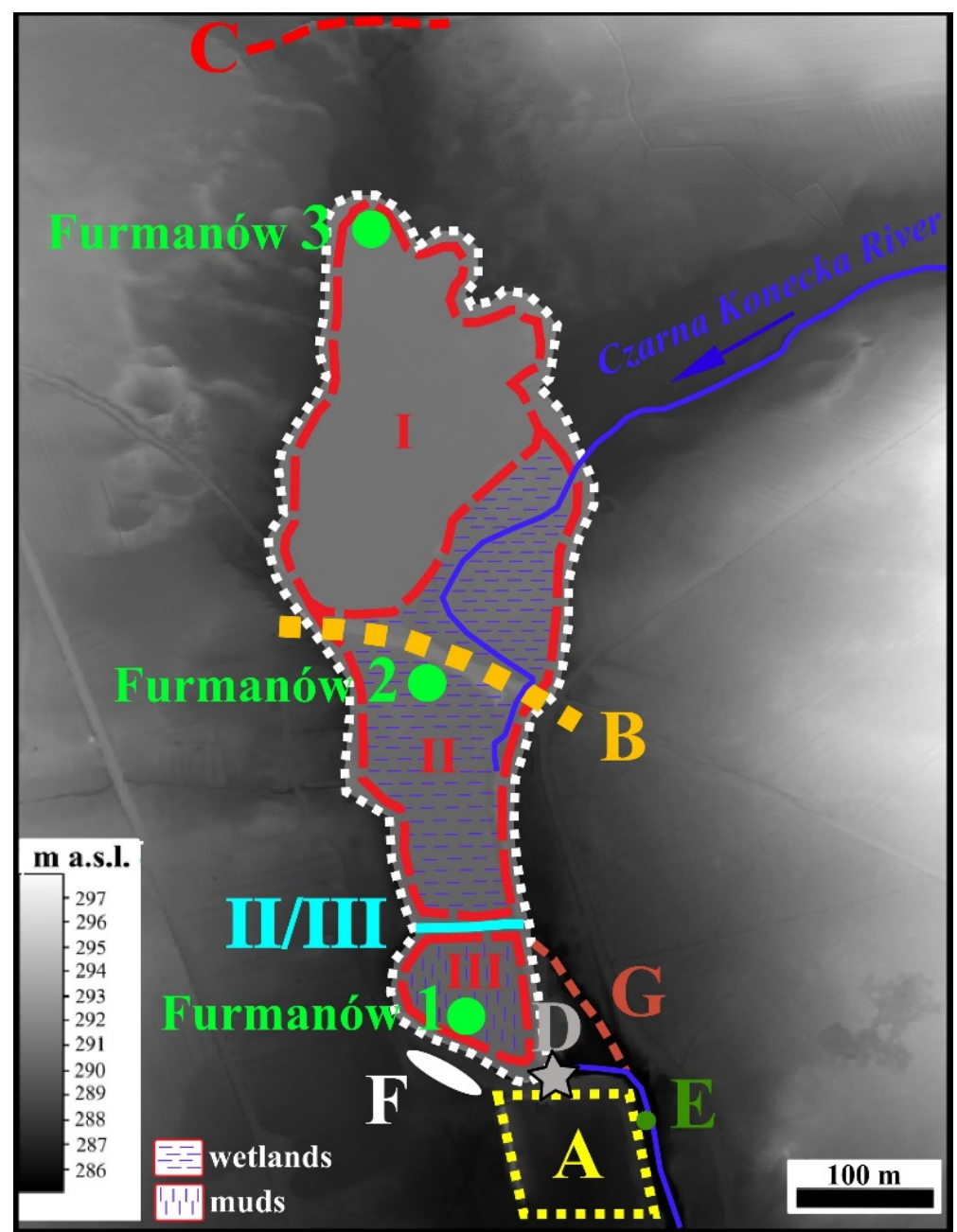

Figure 3. Study area. Hypothetical range (white dashed line) of the former pond by [7]. Furmanów 1, 2 and 3 - drilling locations; I, II and III - parts of reservoir; II/III - beavers dam; A - ruin of blast furnace plant, B - causeway, C - dam, D - location of former weir, E - slag bar, F - pit with slags, G - inactive anthropogenic channel.

\section{AIM OF STUDY AND METHODS}

The aim of this studies is to determine the impact of the development and disappearance of OPID on the transformation of river systems. It is a case study covering the section of Czarna Konecka river at Furmanów that allows to show such changes on a local scale. The research included a query of historical and cartographic materials (Fig. 4), which were verified in the field. Geological drillings were carried out in three parts of the former pond. The grain size of sediment samples was analysed by sieve and laser methods [8]. The particle-size distribution of silty-clayey deposits was determined

\section{RESULTS}

The former reservoir was the largest in the 19th century, at a time of dynamic development of OPID. It probably had an area of about 15.5 ha at that time [7], although, as cartographic materials show, its shape, size and number of water bodies using a Mastersizer 3000 Particle Analyzer from Malvern Instruments. For sandy material, a sieve set in accordance with Deutsches Institut für Normung International Organization for Standardization 3310-1 and British Standard 410-1 norm (sieve size 63-2.8 $\mu \mathrm{m}$ ) was used (dimensions of $200 \times 25 \mathrm{~mm}$ ) in conjunction with a Vibratory Sieve Shaker AS 200 basic. The Folk and Ward parameters [9] have been calculated and the grain size is shown graphically using the GRANULOM program.

were variable. The Czarna Konecka river disemboguing to the reservoir, had one or two anabranches of different course, which was probably connected with regulation and channelization of the section upstream of the pond. 
After the resignation from the water wheels (1890) and discontinued production(1907), a slow process of surface shrinkage of the reservoir took place, until its complete disappearance at the turn of the 1970s and 1980s. Materials from the 21st century show a meandering of the river in the north and its straightening ${ }^{1}$ in the central part of the studied area (Fig. 4).

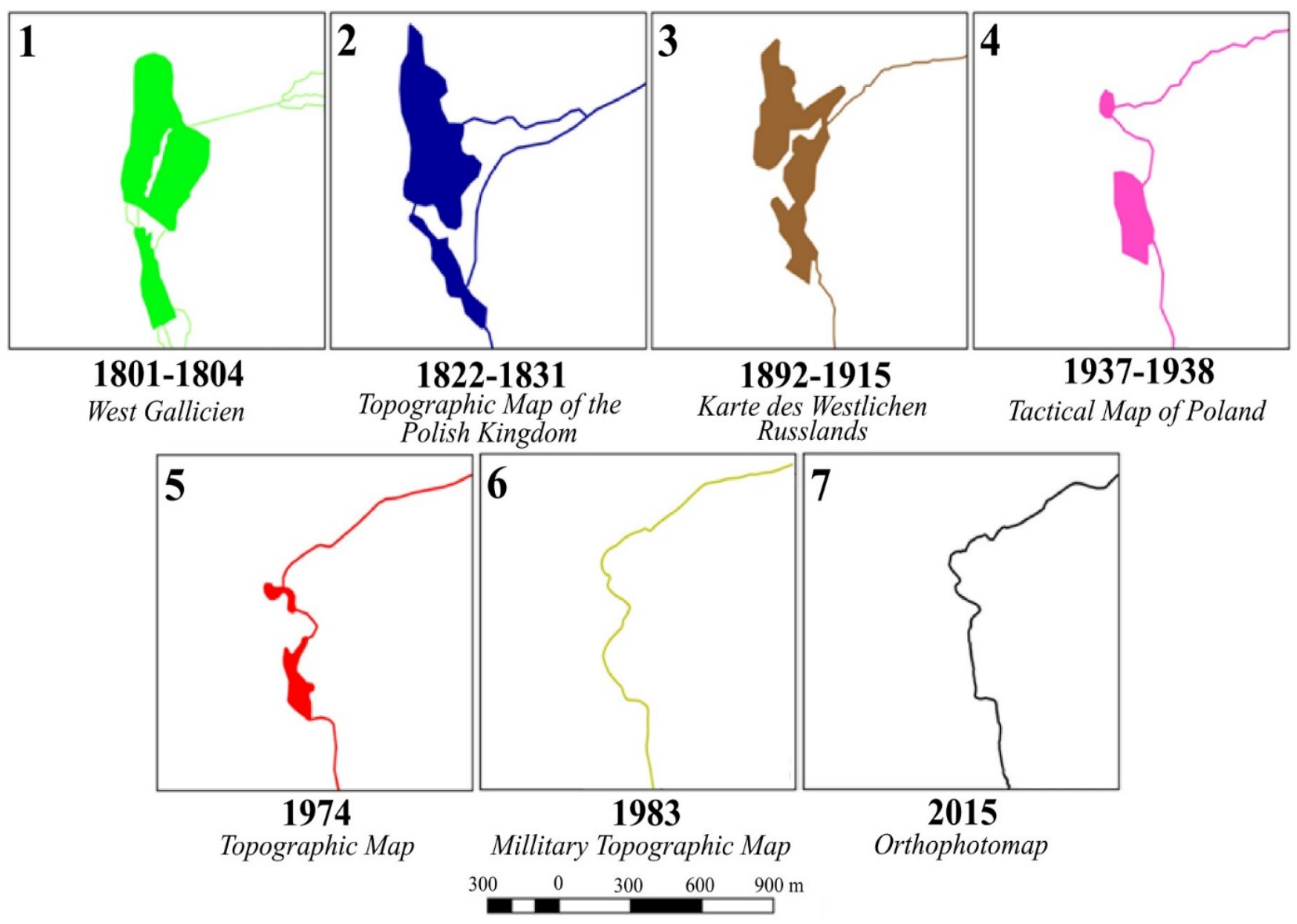

Figure 4. Changes of the study reservoir based on cartographic data in scales: $1: 28800$ (1), ${ }^{2} 1: 126000$ (2), 1:100 000 (3), 1:100 000 (4), 1:50 000 (5), 1:50 000 (6). No data for aerial photo from orthophoto map (7) ${ }^{3}$

The disappearing of the reservoir is taking place at different rates in its various sectors. It is filled with disparate sediments depending on its part (Fig. 3, 5, 6). Three such parts can be distinguished.

The northern part (I in Fig. 3 and 5) covers the area north of the causeway (B in Fig. 3). It is located away from Czarna Konecka riverbed (up to a maximum of about $300 \mathrm{~m}$ ). There is quite stable and poorly wet ground. This is due to a long distance from the river and the existence of a dam (C in Fig. 3) protecting against the inflow of rainwater from the north. Clastic sediments (Furmanów 3 profile) are covered with a thick layer of detritus $(2 \mathrm{~m})$ here
(Fig. 6), which could be accumulated as a result of overgrowing of a reservoir and/or the influence of a whirlpool forming north of the river estuary. This mechanism is similar to the process causing accumulation of slackwater deposits [comp. 10] In the central part (II in Fig. 3 and 5) there is an estuary of the Czarna Konecka river to a former pond. The causeway crosses of a study area here, directing the river towards eastern bank of the former reservoir (Fig. 3). There are wetlands, where the run-off takes place under the surface of the ground. Their existence is favoured by a relief (steep slopes, flat valley bottom, reservoir narrowing southward) and

${ }^{1}$ The regulation of the riverbed was made probably after 2004 (Appendix to Resolution No. XII/15/2004 of the Końskie Poviat Council of 10 March 2004)

${ }^{2} \mathrm{https}$ ://mapire.eu/en/map/firstsurvey-west-galicien

${ }^{3}$ https://mapy.geoportal.gov.pl/imap/Imgp_2.html 
artificial (B in Fig. 3), natural (e.g. II/III in Fig. 3 and 5) obstacles of a drainage. Downstream of a causeway (Furmanów 2 profile) clastic sediments are covered with a thin organic layer $(20 \mathrm{~cm})$. At a depth of 40-60 cm there are slags (Fig. 6), which are waste from metallurgical activity. Their existence in the deposits near a causeway allows us to assume that a former ironworks were located there. This is also evidenced by the three channels which were downstream of a causeway at the beginning of the 19th century (1 in Fig. 4).In the southern part (III in Fig. 3 and 5), downstream of the beaver dam, which currently runs across the entire width of the former
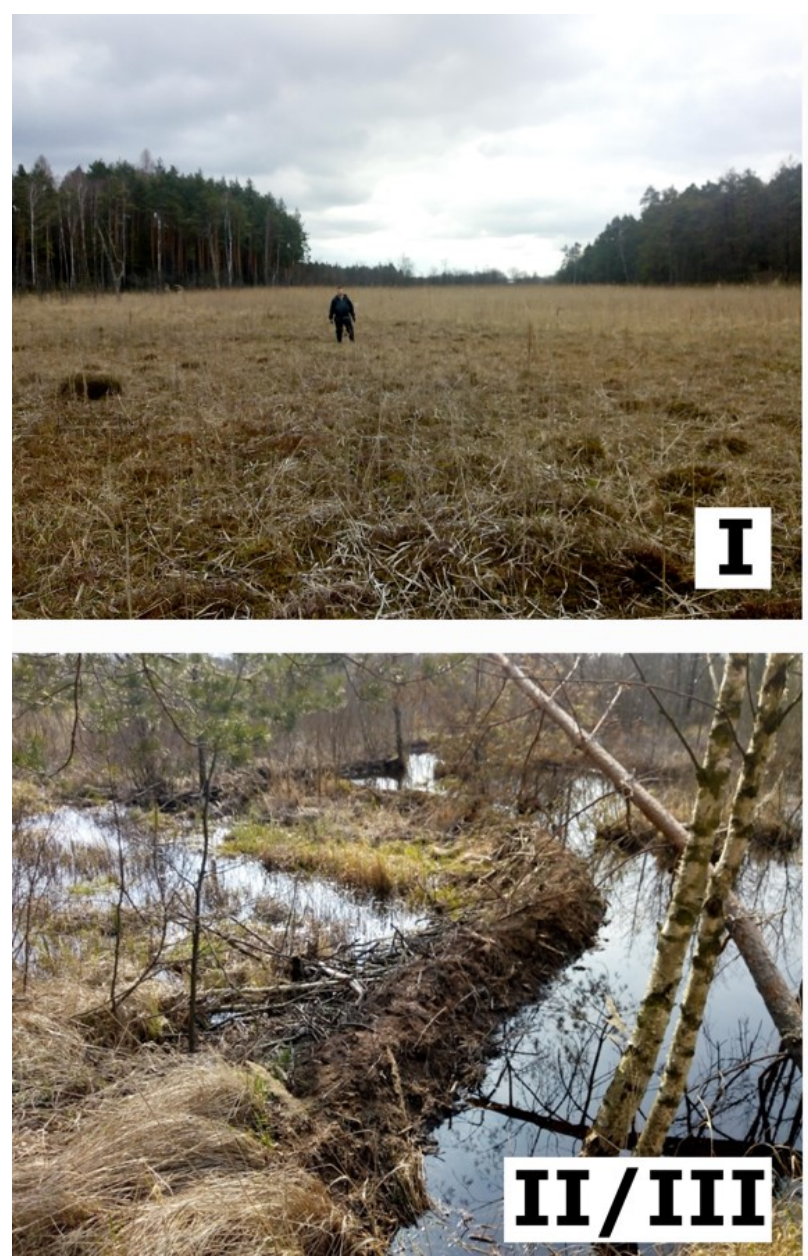

Figure 5. Study area in the northern (I), central (II) and southern (III) parts.

Beaver dam (II/III) between two parts (II \& III) of the former pond. Location see Fig. 3.

\section{DISCUSSION AND CONCLUSIONS}

In the last two centuries, dynamic changes of the analysed reservoir were observed, which were connected with different demand for hydropower in particular years. At the time of OPID development (19th century), the reservoir had the largest surface. Its shape probably depended mainly on hydrotechnical activities. After the resignation
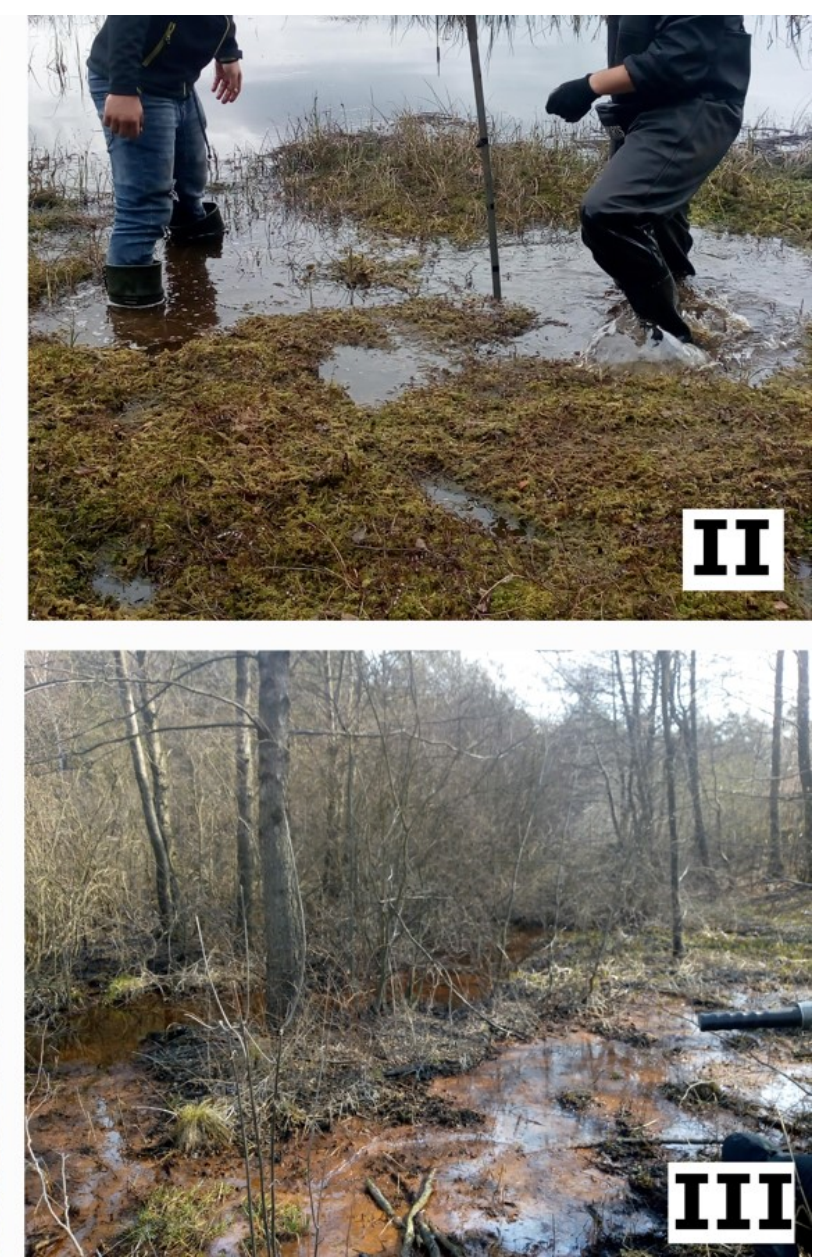

reservoir (II/III in Fig. 3 and 5), there is a muds. In the Furmanów 1 profile, three sediment members (filling stages) have been distinguished - lower, lacustrine $(280-190 \mathrm{~cm})$, with clastic sediments (fining-upward sequence), middle $(190-60 \mathrm{~cm})$, consisting of well sorted $(\delta \approx 0.5)$ medium sands of an inland delta, upper $(60-0 \mathrm{~cm})$, constituting a layer of poorly sorted $(\delta \approx 1.7)$ overbank deposits with a normal sequence (muds), covered with detritus (Fig. 6).In some sectors of the former reservoir, mineral-organic sediments may be deposited by beaver activity [comp. 11].

from water wheels(1890s), it shrunk as a result of progressing natural processes. Reservoir probably ceased to exist after the weir disappearance (D in Fig. 3), which accelerated terrestrialization of the study area in the last decades. The sediments reflect different sedimentation environments in its individual parts. The whirlpool north of the estuary of Czarna Konecka river to the former reservoir is 


\section{FURMANÓW 1}

\section{FURMANÓW 2}

FURMANÓW 3
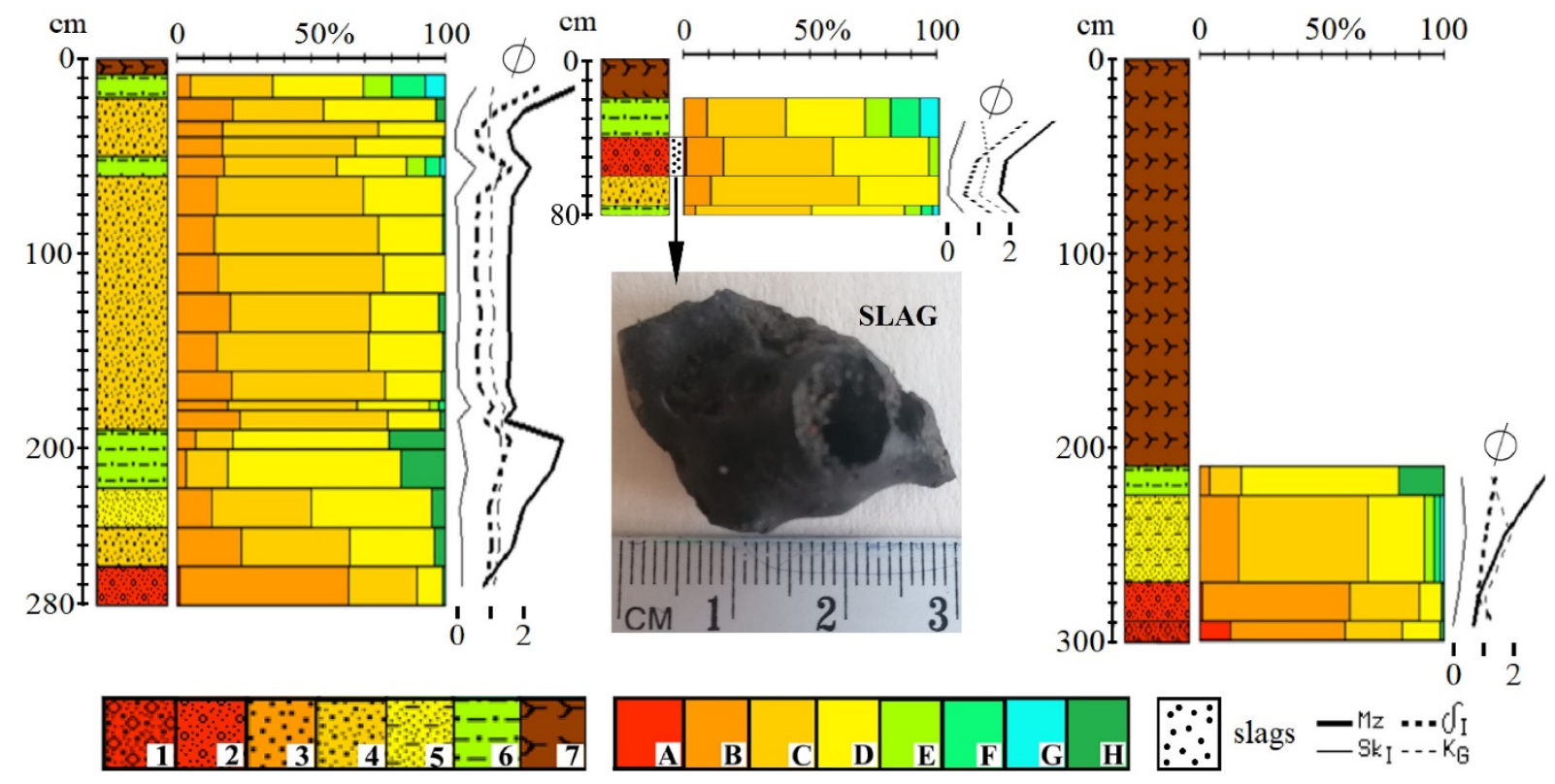

Figure 6. Grain size and Folk-Ward's distribution parameters of sediments in study profiles (location see Fig. 3) Lithology: 1 - sands with gravels, 2 - sands with single gravels, 3 - coarse sands, 4 - medium sands, 5 - silty sands, 6 - sandy silts, 7 - detritus.

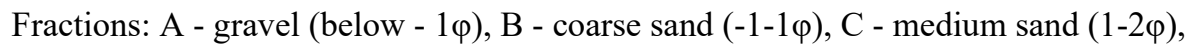

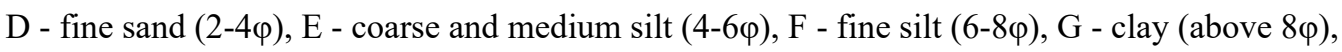

$\mathrm{H}$ - silt and clay (above $4 \varphi$ ); Folk-Ward's distribution parameters of grain size:

$\mathrm{Mz}$ - mean size, $\delta \mathrm{I}$ - standard deviation, SkI - skewness, KG - kurtosis.
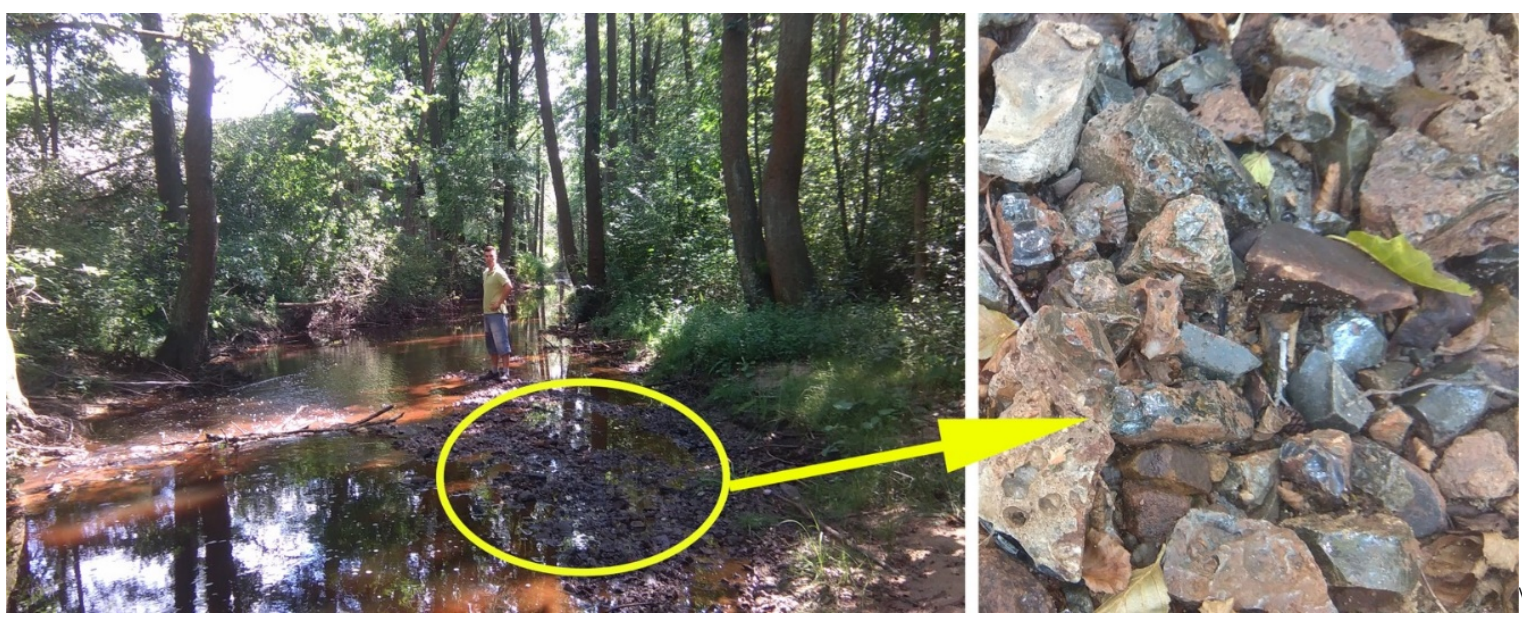

Figure 7. Slag bar in the riverbed near the ruin of a blast furnace plant (location see Fig. 3)

responsible for the accumulation of a very thick detritus layer (Furmanów 3 profile).This sediments can also be connected with overgrowing of a pond (poorly decomposed peat). The almost complete lack of such a layer and features of sediments in the Furmanów 1 profile indicate that filling of southern part of the reservoir is a result of the inland delta progradation, as well as the accumulation of overbank deposits after the disappearance of a pond [comp. 12]. The change of the river course downstream of the reservoir (Fig. 3) and the beavers activity (II/III in Fig. 3 and 5) slows down of terrestrialization processes in the middle sector of the study area. Therefore, even despite an attempt to concentrate the flow of a river south of the causeway (straightening of the riverbed after 2004), there was no headward erosion, incision of deposits and drainage of an area here. Slags identified at Furmanów (Fig. 2, 6, 7, E-F in Fig. 3) are typical artifacts from the last centuries, known from alluvial and lacustrine sediments of the OPID area - comp. [13], [14], [15], [16], [17]. Human impact 
in recent centuries, as with cases of other river sites in the OPID - comp. [14], [16], [17], [18], [19], [20], [21], has led to the reorganization of the river network and change its functioning (creation of a reservoir in the place of the riverbed, stream regulation and channelization). After the fall of industrial activity, the renaturalisation of the valley floor is progressing - terrestrialization, ecological succession, beavers activity. These animals choose former ponds and channels (e.g. G in Fig. 3) in the OPID as their habitats, which is a typical phenomenon recognized in other areas of Poland comp. [22], [23]. After settlement, they the environment shape causing changes in relief and water balance [comp. 24]. This leads to dispersion of the streambed of the seized watercourse [comp. 25]. Thus beavers activity limit the processes typical for a meandering single-bed river. Therefore, historical changes of the valley bottom still condition the hydrological processes shaping the river network today.

\section{REFERENCES}

[1] Chłopek M. Dolina Czarnej: Zapomniane Dziedzictwo, Stowarzyszenie „W Dolinie Czarnej”, Zabytkowy Zakład Hutniczy w Maleńcu, Maleniec, Poland, pp. 1-51, 2017.

[2] Krygier E. \& Ruszczyńska T. Katalog zabytków budownictwa przemysłowego w Polsce, województwo kieleckie, Powiat Końskie, Zeszyt dodatkowy do Kwartalnika Historii Kultury Materialnej, PAN, Wrocław-Warszawa, Poland, vol. 2, no. 1, pp. 49-124, 1958.

[3] Nowak S. Furmanów - u początku miejscowości przemysłowych szlaku rzeki Czarna Konecka [in:] Almanach Świętokrzyski, Stąporków i okolice z historią industrialną w tle, dzieje i czasy współczesne (Nowak S.), Oficyna Wydawnicza Edward Mitek, Warszawa-Bydgoszcz-Kielce, Poland, vol. 2, pp. 171-179, 2017.

[4] Rutkiewicz P. Identifying and Dating Remains of Pond Dams in River Valleys (Southern Poland), International Conference of Computational Methods in Sciences and Engineering (AIP Conference), Greece, vol. 2186, p. $120009,2019$.

[5] Szot-Radziszewska E. Postindustrialne dziedzictwo Staropolskiego Okręgu Przemysłowego w krajobrazie kulturowym Kielecczyzny: zagrożenia i szanse, Ochrona Zabytków, Poland, vol. 62, no. 4, pp. 69-82, 2009.

[6] Zieliński J. Staropolskie Zagłębie Przemysłowe, Zakład Narodowy im. Ossolińskich PAN, Wrocław-WarszawaKraków, Poland, pp. 1-339, 1965.

[7] Rutkiewicz P. \& Malik I. Geomorphological conditions of the location historical ironworks, A contribution to the research based on DEM analysis from LIDAR data, Environmental \& Socio-economic Studies, Poland, vol. 6, no. 4, pp. 11-21, 2018.

[8] Racinowski R., Szczypek T. \& Wach J. Prezentacja i interpretacja wyników badań uziarnienia osadów czwartorzędowych, Wydawnictwo Uniwersytetu Śląskiego, Katowice, Poland, pp. 1-146, 2001.

[9] Folk R.L. \& Ward W.C. Brazos River bar: A study in the significance of grain size parameters, Journal of Sedimentary Research, United States, vol. 27, no. 1, pp. 3-26, 1957.

[10] Kochel R.C. \& Baker V.R. Paleoflood analysis using slackwater deposits [in:] Flood geomorphology (Baker V.R.), Wiley-Interscience, United States, pp. 357-376, 1988.

[11] Śnieszko Z., Rurek M. \& Rzetala M. Significance of relief-forming activities by Castor fiber 1. for the evolution of Holocene floodplains of small river valleys (results of studies conducted in Poland), 17th International Multidisciplinary Scientific GeoConference SGEM, Republic of Bulgaria, pp. 523-529, 2017.

[12] Bajkiewicz-Grabowska E. \& Mikulski Z. Hydrologia ogólna, PWN, Warsaw, Poland, pp. 1-339, 2008.

[13] Przepióra P. Przyrodnicze i historyczne przemiany zlewni Kamionki (Płaskowyż Suchedniowski) w subatlantyku, PhD dissertation typescript, Archives UJK, Kielce, Poland, pp. 1-133, 2017.

[14] Kalicki T., Frączek M., Przepióra P., Kusztal P., Kłusakiewicz E. \& Malęga E. Late Quaternary geomorphology and geoarchaeology in the rivers of the Holy Cross Mountains region, central Europe, Quaternary Research, United Kingdom-United States, vol. 91, no. 2, pp. 584-599, 2019.

[15] Kalicki T., Przepióra P., Chwałek S., Aksamit M., Grzeszczyk P. \& Houbrechts G. Reflection of the metallurgy industry in sediments and relief - case study from Jędrów (Holy Cross Mountains, Poland), 25th Quaternary Conference, Czech Republic, p. 35, 2019. 
[16] Kalicki T., Przepióra P. \& Kusztal P. Anthropogenic flash floods on two selected rivers of Holy Cross Mts. region in 20th c. - origin and effects, Prace i Studia Geograficzne, Poland, vol. 64, no. 1, pp. 21-36, 2019.

[17] Kalicki T., Przepióra P. \& Kusztal P. Origin and effects of anthropogenic flash floods on rivers of Holy Cross Mts. region (Poland) in 20th c., Acta Geobalcanica, Republic of North Macedonia, vol. 5, no. 2, pp. 85-92, 2019.

[18] Kalicki T. \& Fularczyk K. Channel changes of the Krasna riverbed (Holy Cross Mts. region) based on cartographic and geological data, Acta Universitatis Lodziensis, Folia Geographica Physica, Poland, vol. 17, pp. 15-23, 2018.

[19] Kalicki T. \& Fularczyk K. Changes in the course of the Krasna River in the estuary section (Polish Uplands), Proceedings of 5th International Scientific Conference GEOBALCANICA, Republic of North Macedonia, pp. 7582, 2019.

[20] Aksamit M., Kusztal P., Kalicki T., Grzeszczyk P. \& Przepióra P. Silting of the Sielpia water reservoir in the 20th and 21st c. (Central Poland), Proceedings of 5th International Scientific Conference GEOBALCANICA, Republic of North Macedonia, pp. 101-105, 2019.

[21] Kalicki T., Chrabąszcz M., Frączek M., Fularczyk K., Kłusakiewicz E., Kusztal P., Malęga E. \& Przepióra P. Zapis zmian antropogenicznych w formach i osadach dolin świętokrzyskich [in:] Environment - contemporary dilemmas (Żeber-Dzikowska I. \& Chmielewski J.), Instytut Ochrony Środowiska - Państwowy Instytut Badawczy, Warsaw, Poland, pp. 247-280, 2019.

[22] Fajer M., Malik I., Waga J.M., Wistuba M. \& Woskowicz-Ślęzak B. Contemporary adaptation of anthropogenicallytransformed river valleys by European beavers Castor fiber (examples from Poland's Opole Plain and WoźnikiWieluń Upland), Przegląd Geograficzny, Poland, vol. 89, no. 3, pp. 467-489, 2017.

[23] Gorczyca E., Krzemień K., Sobucki M. \& Jarzyna K. Can beaver impact promote river renaturalization? The example of the Raba River, southern Poland, Science of The Total Environment, Netherlands (and other), vol. 615, pp. 1048-1060, 2018.

[24] Kusztal P., Żeber-Dzikowska I., Chmielewski J., Wójtowicz B., Wszelaczyńska E. \& Gaworek B. The significance of the European beaver (Castor fiber) activity for the process of renaturalization of river valleys in the era of increasing, Ochrona Środowiska i Zasobów Naturalnych, Poland-Germany, vol. 28, no. 1, pp. 31-35, 2017.

[25] Pollock M.M., Beechie T.J., Wheaton J.M., Jordan C.E., Bouwes N., Weber N. \& Volk C. Using beaver dams to restore incised stream ecosystems, BioScience, United States-United Kingdom, vol. 64, no. 4, pp. 279-290, 2014. 